\title{
$\mathrm{N} 8 \mathrm{~m} / \mathrm{c}$ ドライヤーパートの操業経験
}

\author{
北越製紙株式会社 新潟工場 工務部抄造第 6 課 吉 川 磨
}

\section{Operating Experience of N 8 Paper Machine Dryer Part}

\section{Osamu Yoshikawa}

Niigata Mill, Hokuetsu Paper Mills. Ltd.

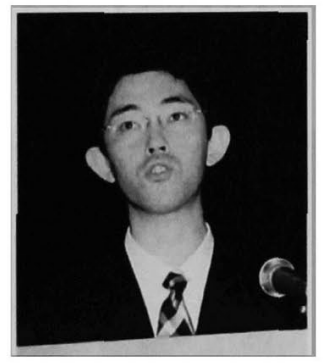

The N 8 paper machine of the Nïgata Mill started up in July 1998, to increase production capacity of coated paper and to improve the paper quality. This machine is the $3 \mathrm{rd}$ large paper machine at Hokuetsu Paper that equipped on-machine coater, and adopted the state-of-the-art technology in the various points to achieve high productivity and good quality together.

We have been in operation for 2 years from the startup of the $\mathrm{N} 8$ paper machine. During operation. the repeating improvement was continuously established to ensure high efficiency and good quality of a higher level.

This paper reports on the operation experience of the dryer part. The focus of topic is SYM-RUN Dryer Section mainly, that equipment was the first introduction to our company.

分類： $M_{7}$ ドライヤー, $M_{1}$ 抄紙・抄紙機一般

\section{1.はじめに}

新潟工場 $8 \mathrm{~m} / \mathrm{c}$ は,コート紙・軽量コート紙の生 産能力向上, 品種構成の充実, 品質の向上を目的 に, 1998 年 7 月に稼動した。生産性・品質の而面から 各所に最新技術を取り入れた当社 3 台目の大型オンコ ーターマシンとして、順調な立ち上げから 2 年を経過 しているが，更に高いレペルの効率と品質を目指し， 現在も改善を進めながら操業を行っている。今回は, 当社にとって初めての導入となった単列ドライヤーを 中心に,ドライヤーパートの操業経験について報告す る。

\section{2. 設 備 概 要}

\section{1 一般仕様}

抄造品種：上質紙，A３コート紙，A２コート紙

$$
\begin{aligned}
& \text { 抄 速: }: 450 \sim 1,200 \mathrm{~m} / \mathrm{min} \\
& \text { 坪 请: } 52.3 \sim 157 \mathrm{~g} / \mathrm{m}^{2} \\
& \text { ワイヤー幅: } 8.050 \mathrm{~mm} \\
& \text { 製 品 幅: } 7.040 \mathrm{~mm}
\end{aligned}
$$

\section{2 抄紙機設備}

$$
\begin{aligned}
& \text { ヘッドボックス：シムフローD（SHI） } \\
& \text { ワイヤーパート：デュオフォーマーD (IHI) } \\
& \text { プスパート：シムブレス O+4 P (SHI) } \\
& \text { ドライヤー：メイン：シムラン(VALMET) (図 1) } \\
& \text { アフター：ダブルカンバス (同上) } \\
& \text { コーター後：ダブルカンバス (同上) } \\
& \text { ゲートロール：TRCコーター (IHI) } \\
& \text { プカレンター：2ロール1ニップ (VALMET) } \\
& \text { コーター：バリドウェルコーター (IHI) } \\
& \text { ソフトカレンダー：MOL カレンター(淀川製鋼所) } \\
& \text { リール：オプティリール (VALMET) }
\end{aligned}
$$




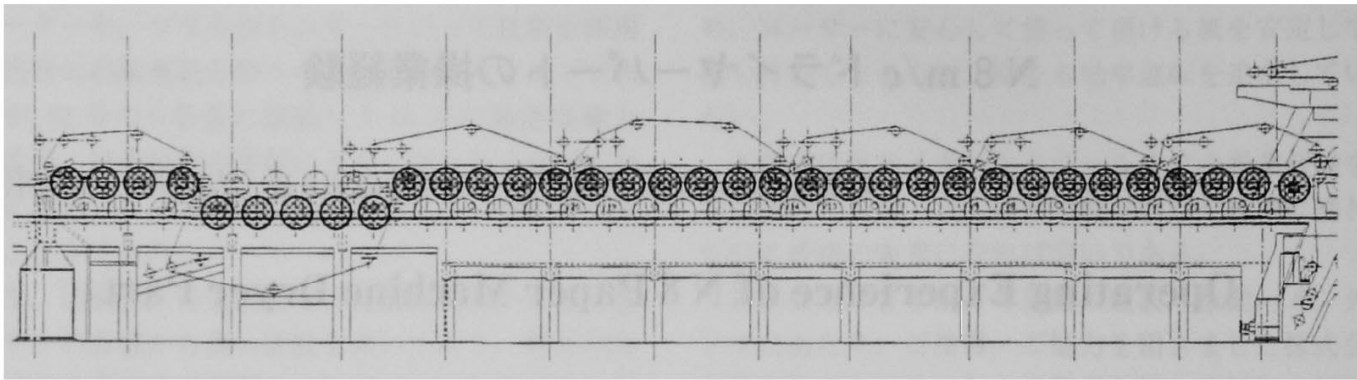

図 1 シムランドライヤー

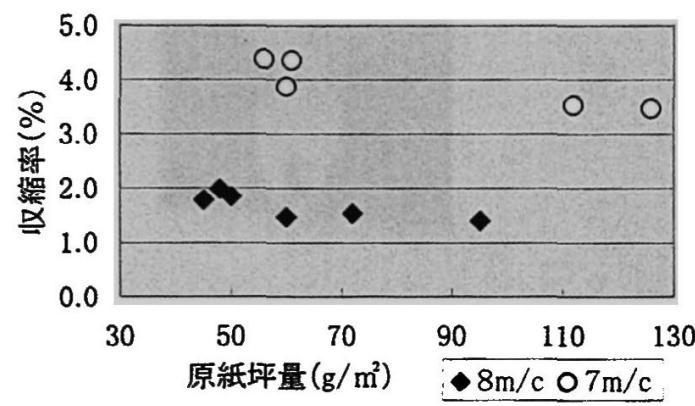

図 2 メインドライヤー収縮率

\section{3 ドライヤー概要}

ドライヤー径：1,830 mm

VACロール径： $1,500 \mathrm{~mm}$

ドライヤー本数（VACロール数）

【メインドライヤー：シムラン】

1 群一 4 本 (3 本), 2 群一 5 本 (5 本), 3 群一 5 本 (5 本), 4 群一 6 本 (6 本), 5 群一 5 本 (5 本), 6 群 (反 転 群) -5 本 (4 本), 7 群一 4 本 ( 3 本), 計 34 本 (31 本)

【アフター・コータードライヤー：タブルカンバス】 8 群一10 本, 9 群一 6 本, 10 群一 8 本

\section{3. ドライヤーパートの操業経験}

\section{1 単列ドライヤー}

乾燥時のシートの安定性と高速時のフラッタリンク 解消の目的より,メインドライヤーには単列ドライヤ 一（シムラン型：VALMET 社）を採用した。

単列ドライヤーの効果として拘束乾婐によるシュリ ンケージの改善は, シートの安定性と並べて大きな改 善目的のひとつであるが，これに関しては十分な効果 が表れている。メインドライヤーでのシートの収縮率 だけを取ってみても，同一紙種を抄造している $7 \mathrm{~m} / \mathrm{c}$ と比較してみると幅の違いはあるものの大きく改善し ていることが解る(図 2)。また，上質紙のカール特 性緩和の対策として 6 群ドライヤーを反転群としたが,

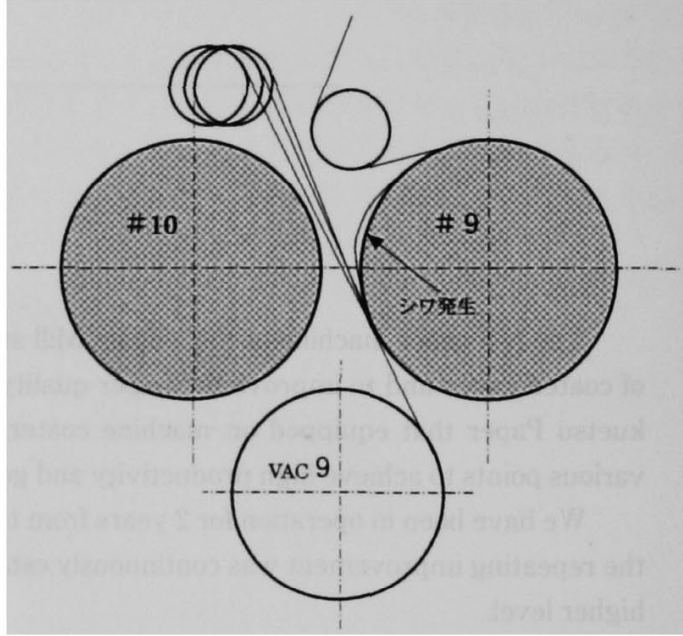

図 3 シムラン群間のシワ

PPC 用紙の抄造においても問題なく操業している。

シムランの群間では, 後群のカンバスを、前群のド ライヤーに接触させることにより，シートの受け渡し を円滑にしているが, メインドライヤー前半のシート 水分の高い群で，この部分に袋状のシワが発生するこ とがあった（図3）。この現象は, 高坪量の品種（原 紙坪量 $80 \mathrm{~g} / \mathrm{m}^{2}$ 以上）で起き易く，ドローを張ること により良化傾向を見せたが, 2-3群間のドロー値で 100.30\%にもなる場合もあった。この現象を改善す る為に, カンバスロールの位置を移動させ, ドライヤ ーシリンターのカンバスへの押し込み量を調整したこ とにより,この部分でのシワの発生は無くなっている。

シングルカンバスの問題点として挙げられていた上 下段の速度差については, 駆動が各群ドライヤーシリ ンダー 2 本を速度制御とし, VAC ロールは負荷分担 制御の 1 本のみ駆動させカンバスの速度差が発生し難 くなっていること, カンバス厚みを極力薄く抑えるこ とで, カンバス厚みによるVAC ロール部での周速差 
を少なくしたこと，等によりこれといった問題は発生 していない。

\subsection{VACロール}

シムランドライヤーの主要部とも言えるVAC ロー ルは，吸引圧を上げていくことで，シートの拘束乾燥 の促進によるメインドライヤーでのシュリンケージの 変化，乾燥効率向上による蒸気使用量の削減等を経験 している。メインドライヤー出口の紙幅では，VAC ロールの吸引を $2 \mathrm{kPa}$ 程変更させたところ, $30 \mathrm{~mm}$ 程 度幅が詰まった。また，原紙坪量 $60 \mathrm{~g} / \mathrm{m}^{2}$, メインド ライヤー出口水分 $7 \%$ 設定の上質紙で, $\mathrm{VAC}$ ロール の吸引压力を $2.3 \mathrm{kPa}$ 変更した場合では, メインドラ イヤーの蒸気使用量で, 1 割弱の変化が見られた(図 4)。 事前の検討では，吸引圧力の真空を上げ過ぎることに よる、VACロール付近のシート走行性やシワ等の態 念があり, 操業当初から, 群毎の吸引圧力の設定バラ ンスの変更や, 設定変更時のシートの走行状態, シワ 等のトラブルの有無の確認を行ってきたが、今のとこ ろ吸引圧力の変更によるトラフルは経験していない。 現在は, 吸引の真空值は通紙時, 操業時もあまり変化 を持たせない操業としている。

VACロールの吸引溝, 穴部の污れや詰まりに関し ては，専用シャワーノズルを使用して水，または圧縮 エアーでの掃除を，現在まで数回行ったが，多少の污 れはあるものの，目詰まりする程の污れはない。

\section{3 紙 切 れ}

シムランドライヤーにおいて反転群を設けることに より，前後のオーブンドロー部での断紙や，断紙時の 下段ドライヤーへの巻き付きによる損紙除去の作業性 の悪さを懸念していたが,ドライヤー切れは少なく(図 5)，さらに反転群付近の断紙はほとんど経験がない。

メインドライヤー内での紙詰まり対策としては， ックオフエアとドライヤードクターの自動着，または 自動加压を併用している(図6)。動作内容は, シー 卜検出器からの断紙信号により, シートの操作側, 駆 動側のエッジ部にエアを吹き付けシートを切断し，全 幅のエアブローによりシートを階トに落とすというも ので，この時手前のドライヤーシリンダーに残紙が巻 き付かないようにドクターも加圧する。以前は，この ドクターを運転中は分離していたため，断䟗時に刃先 に残紙が詰まり，この残紙除去がドライヤーシリンタ 一の面長もあり予想以上に困難であった。これは断紙 時に連動で着となるドクターのシリンダー動作が，エ アフロロに比較してワンテンポ遅れてしまうことに起 因していた。現在は，ドクターを常時微圧にて接触さ せておき，断紙時に加圧することによりほほ解決でき
ている。但し，ドクター刃先に污れが溜まり易い個所 については，更なる改善が必要と考える。

断紙時のシート検出は，基本的に透過式光電管を使 用しているが，メインドライヤー内では，反転群前後 のオープンドロー部でしか使用できないため, VALMET の POSI-EYE シート検出器を併用している。 このセンサーについては, 検出精度の面ではまだ改善 の余地があると考えている。通常運転時には全く問題 の無い検出精度であるが,メインドライヤー通紙直後

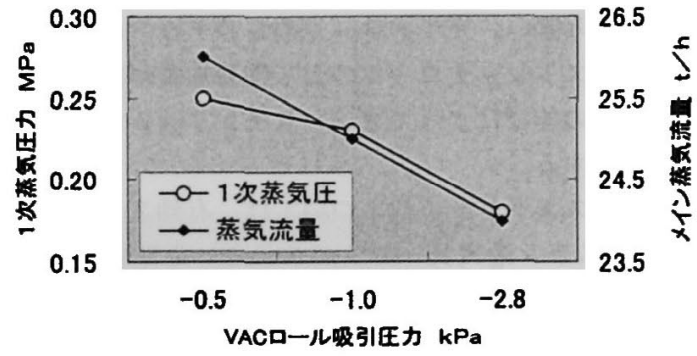

图 4 VAC ロール吸引圧力変更

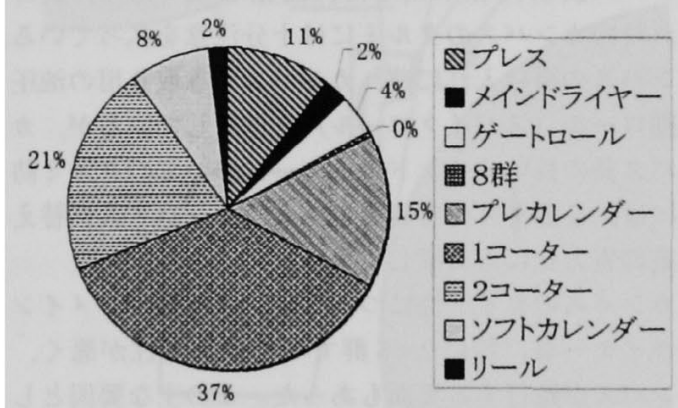

図 58 m c H 12 下期紙切れ実績

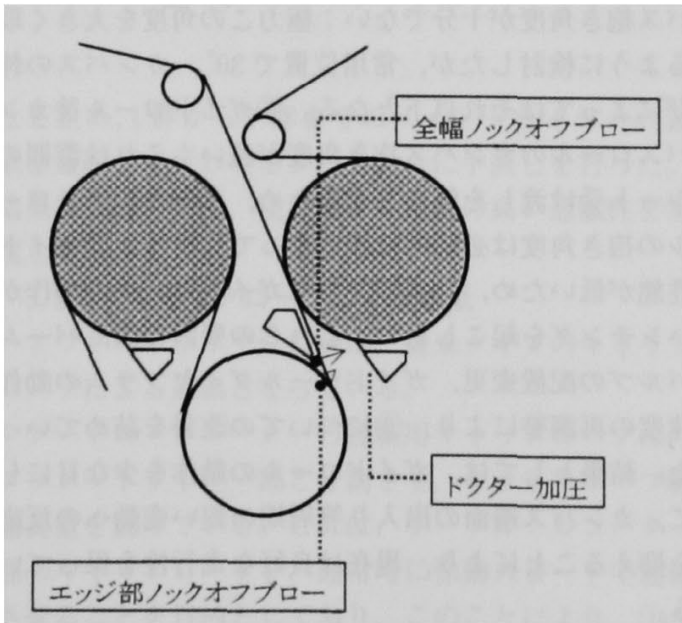

図 6 ドライヤー内シートノックォフ 
の, 温度変化や, 水蒸気の発生が起こり易い状態の時, 条件の悪い群においてのエラーがまれに発生する。こ れについては, 光量自動補正のタイミングや, 検出判 定の 2 重化等検出精度を上げるべく現在検討中である。

\section{4 カンバス污れ}

\subsection{1 カンバスロールのインサイド化}

カンバスロールの污れ蓄積による欠点対策として, カンバスロールのインサイド化を実施した（風切り口 ールは除く)。このことにより，カンバスロール污れ は大幅に改善され，欠点隇少への効果は大きいと認識 している。反面デメリットとして，カンバスストレッ 千代が取り難い，ガイドロールのレイアゥトに制限を 受ける，ストレッチロールの引っ張り加重が同一でも カンバスの伸びによってカンバステンションが変わる 等が発生する。

カンバスストレッチ代については, 有効ストレッチ (カンバスラン最大長一カンバス長さ) を確保するた めに，カンバスの掛け入れ余裕を，カンバスロール移 動装置で捻出することにより対策としている。それで もカンバスの掛け入れ余裕分は, 最も少ない 4 群では カンバス長 $67.8 \mathrm{~m}$ に対して, $1.2 \mathrm{~m}$ 程度であり, 掛け 入れ時のカンバスのタルミには十分注意を払っている。 カンバスの掛け入れには, カンバス巻き取り用の油圧 駆動ロール（スパイクロール）を使用しているが，カ ンバス長の長いメインドライヤーにおいてのタルミ防 止には，必要不可欠な装置といえ，カンバス入れ替え 作業の省力化にも貢献している。

カンバスのガイド性については, 試運転時, メイン ドライヤー群, 特に2〜5 群でややガイド性が悪く， カンバスが蛇行する場面もあった。この主な要因とし ては, 次の項目が考えられる。(1ガイドロールのカン バス抱き角度が十分でない：極力この角度を大きく取 るように検討したが, 常用位㯰で $30^{\circ}$, カンバスの伸 びによってはそれ以下となる。2ガイドロール後カン ハススロルのカンバス抱き角度が浅い：これは群間の シート受け渡しを優先させるため,このカンバスロー ルの抱き角度は必然的に浅くなってしまう。(3)ガイド 性能が低いため, 外乱に対してガイドロールの動作が ハンチンクを起こし易い。これらの要因の内, パーム パルフの配置変更, ガイドロールタイイフラムの動作 速度の再調整により，(3)についての改善を詰めていっ た。結果としては，ガイドロールの動作を少な目にし て, カンバス端面の出入り等周期の短い変動への反応 を抑えることにより，現在は良好な走行性を保ってい る。

カンバステンションの変化については，ストレッチ
ロールの位置によりカンバスの抱き角度が変化する事 に起因している。ストレッチロールはカンバスの伸び によって移動するため, 最もカンバスの伸び易い掛け 入れ後しばらくは，ストレッチロール位置の確認を頻 繁に行い油圧を修正し，その後も定期的にストレッチ 位置は確認するようにしている。

\subsection{2 カンバスクリーナー}

カンバスの污れの対処として，各群に休転時の洗浄 用に水シャワーの配管を設置しているが，特に污れが 憅念されるゲートロールコーター後の 8 群には，エア と高圧水によるカンバスクリーナー装置を設置してい る。この装置は，休転時のカンバス洗浄用は元より， 通常操業時においてもエアのみを使用して効果を挙げ ている。また，環境条件の笽しさより当初心配されて いたモーターによる摺動装置も，現在までトラブルも なく良好な使用状況である。

\section{5 通紙装置}

\subsection{1 ロープレステール通紙}

メインドライヤーの通紙は，エアト゚クター，ウノラ ンプローボックス, VACロールによるロープレステ 一ル通紙となる(図 7)。

プレスパートより＃1ドライヤーに通紙されたテー ルは,エアノズルにより階下に落とされている。これ をノックオフエアにより切断, ドクターエアによりド ライヤー表面より離反しカンバスに押し当てる。カン バスに押し当てられたテールは，ウノランブローボッ クスとVACロールによりカンバス表面に保持され， 次のカンバスとドライヤーのニップへ移動する。これ を綝り返すことにより，メインドライヤーの通紙は進 んでいく。さらに反転群ではガイドエアにより，テー ルの緩みとカンバスからの離反を防止している。これ らのエアノズルの作動は，電磁弁により制御され，テ ンダーの操作はワンボタンのみであり，それぞれのエ ア吐出タイミングを決めるタイマーは, 多品種の抄造 に対応すべく,3 パターンの設定枠を選択できるよう

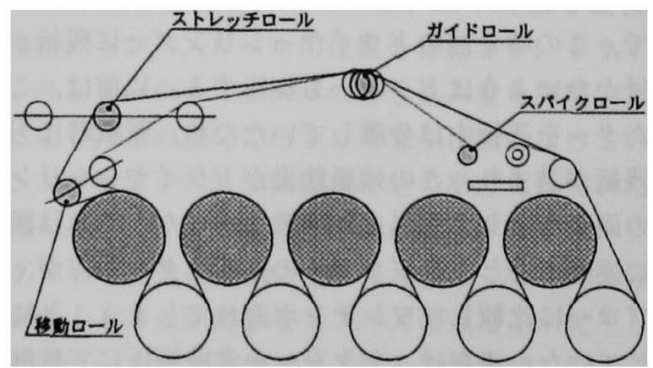

図 7 カンバスロールインサイド化 


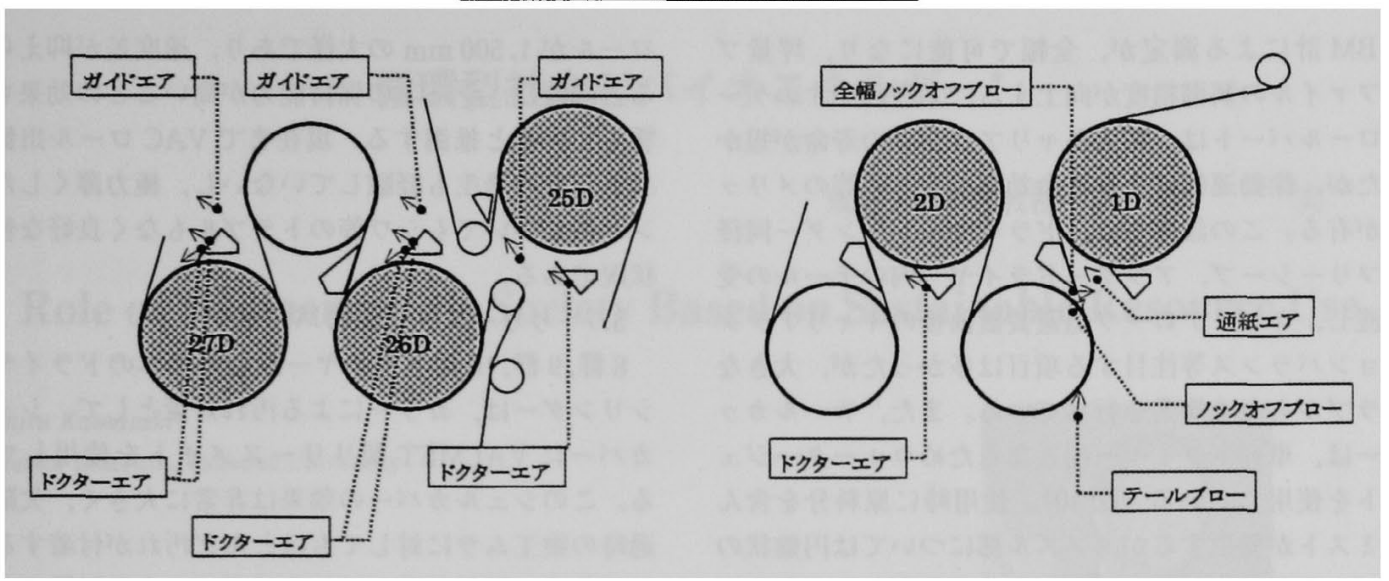

图 8 通紙用エアノスル

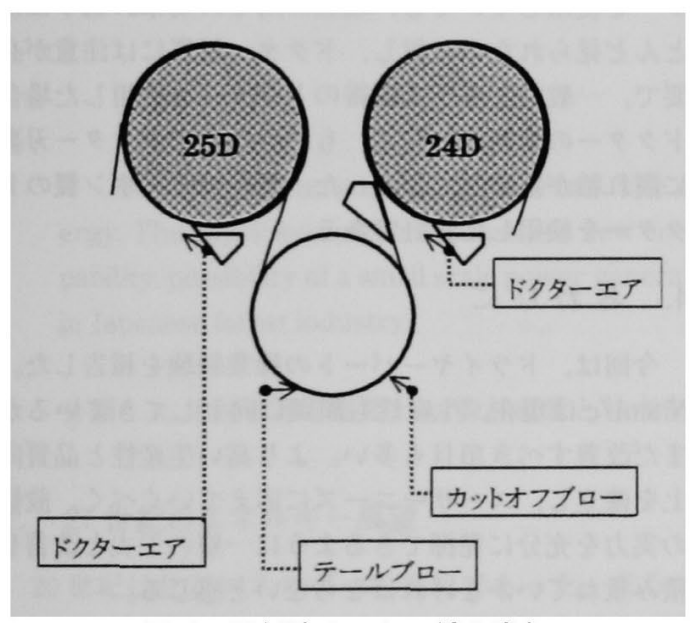

図 9 通秖時テールの緩み取り

にし，低速から高速までそれぞれの通紙タイミングに 合ったスムースな通釈を実現している（図 8)。

スタートアップ時の通紙用エア制御シーケンスは, テールが進むにつれ発生するテールの緩み, テールノ 一スの垂れ下がりを考虑して、3 群後, 5 群後の 2 力所 で一旦テールを階下に落とし緩みを取り，テールノー スを作り直すものであった。動作としては，まず通紙 開始時から群の最終部でテールブローを出しておき, テールが先に進むのを妨げ階下にテールを落とす。次 にテールブロー停止と同時にカットオフブローにより 再度テールを切り，テールノースを作った後で次群人 通紙を再開させるものであった（図 9)。この方法で も通紙性は良好といえる部類であったが，高速時や， 高坪量抄造時に, 乾燥が進んだテールをカットオフフ ローで上手く切断出来ないことにより，通紙精度を下 げる場面もあった。そこで，途中でテールを落とすこ

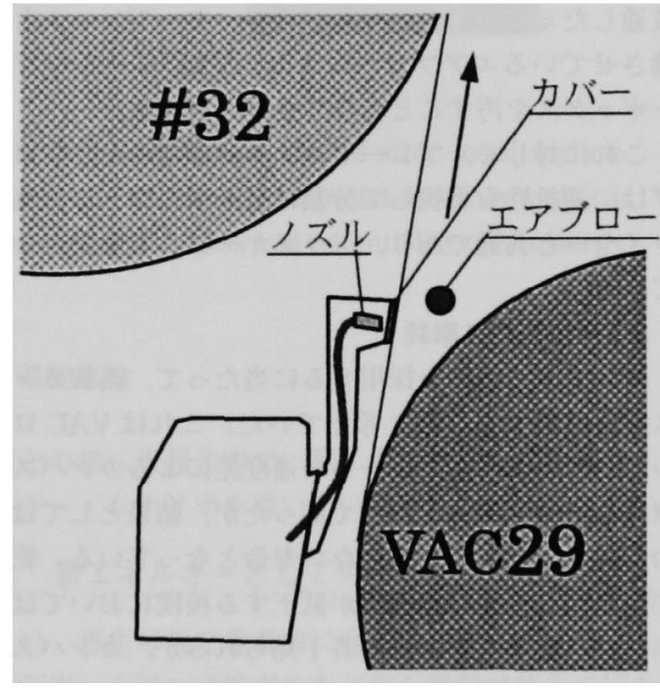

図 10 ウォータージェット

とを止め, 1 群から 7 群までのメインドライヤーの通 紙を連続して行わせるシーケンスに手直しを行った。 結果は良好であり, 現在はより精度の高い通紙性を実 現している。

\subsection{2 キャリアロープによる通紙}

アフタードライヤー以降は, 従来タイプのキャリア ロープによる通紙となっている。

ゲートロールコーターの通紙用キャリアロープは, アフタードライヤー部と分割させ, キャリアロープ駆 動装置を設けている。これは, ゲートロールコーター 部のキャリアロープを, 通常時に徐動スピードで運転 させることを目的としており，このことにより，(1) キ ヤリアロープ退避装置により, メインドライヤー出口 
のBM 計による測定が, 全幅で可能になり, 坪量フ ロファイルの制御精度が向上する, (2)污れやすいゲー トロールパートは, 従来キャリアロープの寿命が短か ったが，徐動運転により延命効果が大きい等のメリッ トが有る。この設備では, ドライヤーシリンダー同径 のフリーシーブ, アフタードライヤー内のテールの受 け渡し, キャリアロープ退避装䀠前後のキャリアテン ションバランス等注目する項目は多かったが、大きな トラフルもなく操業を行っている。また，テールカッ ターは, 単列ドライヤー内となるためウォータージェ ットを使用している（図 10）。使用時に原料分を含ん だミストが発生するが，ノズル部については円盤状の カバーがあり，一回の使用程度では問題となる程の污 れはないが、切り口を良好に保つためにはノスル部に 原料粕を蓄積させないことが重要である。カンバスを 貫通したミストについても，ウォータージェットと連 動させているエアフローにより，VACロールやフロ 一ボックスを污すこともなく良好と言える。

これに対して，プードコーター部のキャリアロー プは，通紙性を重視して分割は行わず、コーター後ド ライヤーと共通であり，ドライヤーによる駆動となっ ている。

\section{6 カンバス摩耗}

単列ドライヤーを採用するに当たって, 当初カンパ ス寿命は低下する物と考えていた。これはVACロー ル部でのカンバスとシートの速度差によるカンバスの 摩耗を予想していたためであったが, 結果としては他 のパートに比较して趢色ない寿命となっている。乾嬠 が進み, シートの伸縮性が低下する後段においては, ペーパーサイドの糜耗も若干見られるが，カンバスの 强度に表れる程ではなく, 强度はやはりロールサイド の摩耗に左右されている。前述にもあるが、カンバス の厚みが $1.7 \mathrm{~mm}$ と薄く抑えられていることと, VAC
ロールが $1,500 \mathrm{~mm}$ の大径であり，速度差が抑えられ ると同時に, シートの保持能力が高いことの効果も影 響していると推測する。現在までVACロール出側の フクレ等の発生も経験していないし, 極力薄くしたカ ンバスについてもシワ等のトラブルもなく良好な使用 状況である。

3.7 リリースメイトカバー材

8 群, 9 群, 10 群ドライヤー最初の 2 本のドライヤー シリンターは, カラーによる污れ対策として, シェル カバーにVALMET 製リリースメイトを使用してい る。このシェルカバーの効果は非常に大きく， 久宿通 過時の塗工ムラに対してもほとんど污れが付着するこ とはなく，乾燥が進んでいるはずの 3 本目以降のドラ イヤーが污れやすい程である。また、ドライヤードク ターを使用していても，現在の所その効果の低下はほ とんど見られない。但し，ドクター材質には注意が必 要で,一般的なガラス繊維のドクターを使用した場合， ドクターの摩耗が著しく，ものの数分でドクター刃产 に削れ粕が蕃皘してしまった。現在はカーボン製のド クターを使用して良好である。

\section{4. おわりに}

今回は,ドライヤーパートの操業経験を報告した。 $\mathrm{N} 8 \mathrm{~m} / \mathrm{c}$ は現在, 生産性も順調に向上してきているが, まだ改善すべき項目も多い。より高い生産性と品質向 上を確立し，ユーザーニースに応えていくべく，設備 の実力を充分に発揮できるように一層の工夫と改善を 稓み重ねていかなければならないと感じる。

最後に, N $8 \mathrm{~m} / \mathrm{c}$ は各パート毎に機械メーカーが異 なるが，操作方法や回路構成等各メーカーに当抄紙機 の統一仕椂を理解して頂いたお险で, N $8 \mathrm{~m} / \mathrm{c}$ の順調 な立ち上がりに結びついたことを感謝しつつ結びとす る。 


\section{報文概 要一管}

最新製紙技術とドライヤーカンバス

敖島カンバス株式会社 技術部 大森 良行

抄紙機のドライヤーパートは多筒式ドライヤーが開発されて以来, 乾燥理論や機械構造の大きな変化 はないものの着実に広幅化と高速化が進んできている。その最新製紙技術として高速抄紙をポイントに ドライヤーカンバスに関する弊社の研究内容を紹介する。特に今後主流となると予想される単列ドライ ヤーシステム用カンバスについて, 棈造, 通気度, 表面性, 光反射特性を詳しく説明する。あわせて単 列ドライヤーとエアーキャップを併用したドライヤーに関する知見を報告する。

また，古秖利用が進む中でカンバス污れによる久点や断紙の有効な解決策の一つとしてカンバスロー ルのオールインサイド化について紹介し，カンバスの走行安定性に関する知見を報告する。

その他の項目として, カンバスの表面性, 随伴空気流, シート走行安定装睤との相互関係についての 報告の他, カンバスの安定摷業への工夫, 最近の高機能素材に付いても言及する。

(本文 46 ページ)

\section{1 号抄紙機ドライパートの操業経験}

\section{大昭和製䉻株式会社 本社工場 吉永製紙部 伊藤 学、畔高 潤}

51 号抄紙機は，既設の 4 台のマシンで抄造していた特殊板紙を移抄するとともに，新たに高級板紙 の分野にも進出すへく，平成 4 年 5 月に稼動した。日産能力は $250 \mathrm{t}$, ワイヤー幅は $3,950 \mathrm{~mm}$, リール 紙幅は 3,550 mm, 設計抄速は $450 \mathrm{~m} /$ 分であり, マシン本体設備および主要付带設備は小林製作所より 供給されている。操業開始から8 年が経過した現在でも, 印刷適性，作業性などの品質面において，各 ユーザーの皆様から高い評価を頂いている。

51 号はオンマシン上に4コーターヘッド+2 スタックのソフトカレンダー+6段 2 スタックのハード

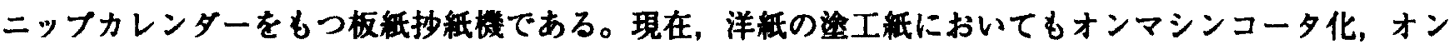
マシンカレンター化が進行しつつあるが, 51 号はその先駆けとして, 操業性・作莱性・生産性・省力化 の面から様々な技術が集䄪されたマシンであると言える。設備単体では目立った最新技術はないが，ア フタードライヤ以降の操莱安定性にはかなりの英知を注き込んできた。

本報では 51 号抄紙機の設備概要と，ドライヤーからリールまでの操羓経験を中心に報告する。

(本文 56 ページ)

\section{$\mathrm{N} 8 \mathrm{~m} / \mathrm{c}$ ドライヤーパートの操業経験}

\section{北越製紙株式会社 新舅工場工務部抄造第 6 課 吉川 磨}

新潟工場 $8 \mathrm{~m} / \mathrm{c}$ は, コート纸・軽量コート紙の生産能力向上, 品種構成の充実, 品質の向上を目的 に, 1998 年 7 月に稼锄した。生産性・品啠の両面から各所に最新技術を取り入れた当社 3 台目の大型才 ンコーターマシンとして，順調な立ち上げから 2 年を経過しているが，更に高いレベルの効率と品質を 目指し，現在も改善を進めながら操莱を行っている。この報文は，当社にとって初めての導入となった 単列ドライヤーを中心に，ドライヤーパートの操業経験について述べている。

$\mathrm{N} 8 \mathrm{~m} / \mathrm{c}$ のメインドライヤーは, マシンスピードの高速化に伴い, より安定した走行性と品資を確保 すへく、シムランドライヤーを学入している。シムランドライヤーは, 反転群の操業性, サクションロ 